\title{
REDUCTION IN PLASMA CHOLINESTERASE LEVELS AFTER PROLONGED ADMINISTRATION OF ECHOTHIOPHATE IODIDE EYEDROPS*
}

\author{
T. E. EiLderton, D.D.s., O. Farmati, M.D., AND E. K. Zsigmond, M.D. $\dagger$
}

\begin{abstract}
Echothiophate IODIDE (ECH) (phospholine iodide), a potent miotic when used in conjunctival instillation, has gained increasing popularity in recent years for the treatment of chronic glaucoma and for concomitant esotropia. ${ }^{1}$ Soon after its introduction into clinical practice, both local and systemic side-effects were reported by several investigators. ${ }^{2-6}$ Since a potent inhibitory effect of ECH on both the true (red cell and brain) cholinesterases and pseudo (plasma and liver) cholinesterases of man both in vitro and in vivo was reported, ${ }^{7,8}$ it was not unexpected when cases were recently reported of prolonged apnoea after administration of succinyldicholine dichloride in patients who received ECH eyedrops for prolonged periods. ${ }^{0,10}$ Although the appearance of cholinergic sideeffects is primarily dependent on the inhibition of true cholinesterase, the inhibition of human plasma pseudocholinesterase is of greater importance to anaesthesiologists because the detoxification of succinylcholine and the ester-type local anaesthetics primarily depends on their enzymatic hydrolysis by pseudocholinesterase. ${ }^{11,12}$

In view of the above findings, the laboratory determination of the pseudocholinesterase activity was carried out in patients undergoing treatment with ECH eyedrops.
\end{abstract}

\section{Materials and Methods}

Seventy-one patients, treated with ECH eyedrops for periods of two months to seven years, were selected at random. The only reason for the exclusion of patients from the study was a clinical history or evidence of liver impairment, because liver damage reduces pseudocholinesterase activity. ${ }^{13}$

Table I presents the age and sex distribution of the patients. The division of age groups was based on the observed differences in pseudocholinesterase activity of normals. ${ }^{14}$ Since the pseudocholinesterase activity of females was reported to be significantly lower than that of males ${ }^{15}$ probably because of the reduced levels observed during pregnancy, ${ }^{16}$ the patients were grouped according to sex. The sex difference, however, has little bearing on our results, for only 30 per cent

'From the Anesthesia Research Laboratory and the Department of Anesthesiology, Allegheny General Hospital, and the Department of Anesthesiology, Eye and Ear Hospital, University of Pittsburgh, School of Medicine, Pittsburgh, Pennsylvania.

tDr. Eilderton is Senior Resident in Oral Surgery, Montefiore Hospital, Pittsburgh, Pennsylvania, and Postdoctoral Fellow in the Anesthesia Research Laboratory, Allegheny General Hospital, Pittsburgh. Dr. Farmati is Director of the Anesthesia Department, Spencer Hospital, Meadville, Pennsylvania. He is also Assistant Professor in Anesthesiology and Clinical Research Associate in Pharmacology, University of Pittsburgh School of Medicine. Dr. Zsigmond is Anesthesiologist and Director of the Anesthesia Research Laboratory, Allegheny General Hospital, Pittsburgh. Correspondence and requests for reprints should be sent to Dr. Zsigmond, 
TABLE I

Age and Sex Distribution of the Patients

\begin{tabular}{lccc}
\hline & \multicolumn{3}{c}{ Sex distribution } \\
\cline { 2 - 4 } Age groups & male & fenale & total \\
\hline 6 mos. -2 yrs. & 0 & 1 & 1 \\
$2-15$ yrs. & 7 & 11 & 18 \\
15-65 yrs. & 14 & 12 & 26 \\
Over 65 yrs. & 14 & 12 & 26 \\
All age groups & 35 & 36 & 71 \\
\hline
\end{tabular}

of the females fell into the childbearing age. Similarly, none of the patients belonged to the age group below six months. Therefore, no consideration need be given to the low pseudocholinesterase values observed in the neonatal period. ${ }^{17}$

The duration of treatment with $\mathrm{ECH}$ in the various age groups is presented in Table II. In the age group between 0 and 15 years, 19 patients were treated for accommodative esotropia. Therefore, 15 of these patients received treatment from six months to two years. Only two patients received therapy for more than the two-year period. In contrast, 52 patients in the age groups of 15 to 65 years and over 65 years were equally distributed in the three treatment periods. The average duration of treatment on $\mathrm{ECH}$ in 21 patients treated over two years was approximately five years.

TABLE II

Duration of the TREaTMENT With Echothiophate

\begin{tabular}{lccr}
\hline Age groups & $<6$ mos. & 6 mos. -2 yrs. & $>2$ yrs. \\
\hline 6 mos.-2 yrs. & 1 & 0 & 0 \\
$2-15$ yrs. & 1 & 15 & 2 \\
$15-65$ yrs. & 8 & 9 & 9 \\
Over 65 yrs. & 6 & 10 & 10 \\
All age groups & 16 & 34 & 21 \\
\hline
\end{tabular}

The patients received approximately two drops of $\mathrm{ECH} 0.06$ per cent solution in each eye three times a week.

\section{Laboratory Studies}

Heparinized fasting-state blood samples were immediately entrifuged at 2600 r.p.m. for 20 to 30 minutes and the plasma was separated. The samples were kept in a refrigerator at $4^{\circ} \mathrm{C}$. until measurements were made. The plasma cholinesterase activity of the patients was determined by Kalow's spectrophotometric method. ${ }^{18}$ The hydrolysis rates of $5.0 \times 10^{-5} \mathrm{M}$ of benzoyl choline chloride and procaine hydrochloride respectively were studied. Dilutions of heparinized human plasma were 1:200 for benzoylcholine and 1.10 for procaine in a phosphate buffer at $\mathrm{pH} 7.4$ and at $37^{\circ} \mathrm{C}$. All determinations were carried out in duplicate within 24 hours after the blood samples were taken. 


\section{Results and Discussion}

\section{Patients with Normal Hydrolysis Rates}

The mean hydrolysis rates of benzoylcholine and procaine by the pseudocholinesterase of 45 patients with normal activity are presented in Table III. The rates were considered normal when both substrates were hydrolysed at a rate greater than 66 per cent of normal values formerly reported. ${ }^{12,18}$

When the patients were grouped according to the duration of ECH treatment, no correlation was observed between the duration of treatment and the hydrolysis rates of the substrates, since, out of 45 patients with normal activity, ten patients (22\%) had received treatment for over two years, ten patients (22\%) for less than six months, and 24 patients (56\%) for six months to two years (see also Table V).

\section{Patients with Reduced Activity}

The mean hydrolysis rates of benzoylcholine and procaine by pseudocholinesterase of 26 patients with reduced activity are summarized in Table IV. From the comparison of Table IV with Table III, it is evident that the hydrolysis rates for both benzoylcholine and procaine were reduced two to threefold as compared to normal. When the hydrolysis rates of benzoylcholine and procaine were regrouped according to the duration of the treatment, as shown in Table V, chi-squared tests showed no definite correlation between the duration of treatment and the mean hydrolysis rates. Based on these results, however, one out of four

TABLE III

Hydrolysis Rates of Benzoylcholine and Procaine of Patients with Norial Cholinesterase Activity

\begin{tabular}{lcccccc}
\hline & & \multicolumn{4}{c}{ Hydrolysis rates* } \\
\cline { 3 - 6 } \multicolumn{1}{c}{ Sex } & $\begin{array}{c}\text { Average } \\
\text { age }\end{array}$ & mean & S.D. & & \multicolumn{2}{c}{ procaine } \\
\cline { 3 - 6 } \cline { 5 - 7 } mean & S.D. \\
\hline Males (15) & 45 & 104.5 & 29.56 & & 1.12 & 0.23 \\
Females (30) & 42 & 81.4 & 23.02 & & 1.09 & 0.34 \\
Group (45) & 43 & 89.1 & 27.37 & & 1.10 & 0.31 \\
\hline
\end{tabular}

*Expressed as $\mu$ moles of substrate hydrolysed by $1 \mathrm{ml}$. plasma in one hour.

TABLE IV

Hydrolysis Rates of Benzoylcholine and Procaine of Patients with Reduced Cholinesterase Activity

\begin{tabular}{lcccccc}
\hline & & \multicolumn{4}{c}{ Hydrolysis rates* } \\
\cline { 3 - 7 } \multicolumn{1}{c}{ Sex } & $\begin{array}{c}\text { Average } \\
\text { age }\end{array}$ & benzoylcholine & & \multicolumn{2}{c}{ procaine } \\
\cline { 3 - 4 } \cline { 5 - 7 } Males (20) & 56 & 44.0 & 15.88 & & 0.551 & 0.187 \\
Females (6) & 61 & 28.0 & 16.06 & & 0.368 & 0.138 \\
Group (26) & 57 & 40.3 & 17.06 & & 0.507 & 0.174 \\
\hline
\end{tabular}

*Expressed as $\mu$ moles of substrate hydrolysed by $1 \mathrm{ml}$. plasma in one hour. 
TABLE $V$

\begin{tabular}{|c|c|c|c|c|}
\hline \multirow{2}{*}{$\begin{array}{c}\text { Duration of } \\
\text { treatment }\end{array}$} & \multirow{2}{*}{$\begin{array}{l}\text { Type of PCHE } \\
\text { activity }\end{array}$} & \multirow{2}{*}{$\begin{array}{l}\text { No. of } \\
\text { patients }\end{array}$} & \multicolumn{2}{|c|}{ Hydrolysis ratest } \\
\hline & & & bech. & proc. \\
\hline Less than & normal & $10(63 \%)$ & 89.18 & 1.151 \\
\hline 6 months (16) & reduced & $6(37 \%)$ & 39.78 & 0.287 \\
\hline $\begin{array}{l}6 \text { months to } \\
2 \text { years (34) }\end{array}$ & $\begin{array}{l}\text { normal } \\
\text { reduced }\end{array}$ & $\begin{array}{r}25(74 \%) \\
9(26 \%)\end{array}$ & $\begin{array}{l}90.10 \\
44.93\end{array}$ & $\begin{array}{l}1.117 \\
0.550\end{array}$ \\
\hline More than & normal & $10(48 \%)$ & 86.40 & 1.016 \\
\hline 2 years $(21)$ & reduced & $11(52 \%)$ & 36.88 & 0.546 \\
\hline
\end{tabular}

*The results of the above chi-squared tests indicate that there is no correlation between duration of treatment and the hydrolysis rates for males and females.

$\dagger$ Expressed as $\mu$ moles of substrate hydrolysed by $1 \mathrm{ml}$. plasma in one hour.

patients (26\%) after six months to two years treatment, and one out of two (52\%) patients with over two years of ECH treatment may be expected to have twofold to threefold reduction in pseudocholinesterase levels.

\section{The Relation of Pseudocholinesterase Level to the Possible Occurrence of Prolonged Apnoea}

Our results indicate that of the total number of patients studied, 37 per cent showed at least a 50 per cent reduction of pseudocholinesterase activity. One out of seven patients on ECH treatment had a fourfold reduction. Foldes et al. ${ }^{2}$ observed that a twofold reduction in pseudocholinesterase activity results in twofold prolongation of apnoea after the intravenous administration of succinylcholine. Therefore, an identical, moderate prolongation of apnoea may be expected after the administration of succinylcholine to one patient out of three on chronic ECH treatment. A markedly prolonged apnoea, however, is likely to develop in only one out of seven patients with a reduction of cholinesterase activity to 20-25 per cent of the normal level, as formerly observed in patients with severe liver damage. ${ }^{12}$ Caution must be exercised in the administration of succinylcholine to these patients. Indeed, two recent reports, ${ }^{0,10}$ document the occurrence of prolonged apnoea after large doses of succinylcholine in patients on ECH treatment.

It is important to emphasize that succinylcholine should be used with caution when large amounts of the ester-type hydrolysable local anaesthetics are used for epidural anaesthesia, since the onset, severity, and duration of toxic reaction caused by these drugs are directly related to their enzymatic hydrolysis rates, after accidental intravascular injection or systemic absorption. ${ }^{13}$

It is of clinical interest that in one patient the hydrolysis rate of benzoylcholine (7.56 $\mu$ moles $/ 1 \mathrm{ml}$. of plasma $/ 1 \mathrm{hr}$.) was so low that it aroused suspicion that this individual possessed an atypical pseudocholinesterase. Determination of the dibucaine number by Kalow's method ${ }^{21}(\mathrm{DN}=0$ ) substantiated this assumption. Since this anomaly occurs in one out of 3,000 individuals, its occurrence was likely due to chance. It is surprising, however, that this patient, otherwise resembling the other patients presented, had shown no clinical evidence of increased cholinergic systemic activity while on $\mathrm{ECH}$ treatment. 
Although it has been claimed ${ }^{4}$ that the determination of red cell cholinesterase activity is a more valid index of systemic absorption of echothiophate than pseudocholinesterase, neither our results nor the relative in vitro inhibitory effect of ECH on plasma and red cell cholinesterase substantiates this assumption. ${ }^{8} \mathrm{We}$ feel that the determination of pseudocholinesterase activity serves as an accurate estimate of the degree of systemic absorption of ECH.

Special caution must also be exercised with persons who are in contact with insecticides or who are receiving some cytostatic anti-cancer drug, because of the additive and cumulative inhibitory effect of these medications with $\mathrm{ECH}$ on cholinesterases. ${ }^{22}$

\section{SUMMARY}

Plasma cholinesterase activity was determined in 71 patients receiving echothiophate eyedrops. A twofold reduction in plasma cholinesterase activity was found in one-third of the patients and a fourfold reduction in one of every seven patients on echothiophate eyedrops. No correlation was found between the duration of the treatment and the plasma cholinesterase levels found in any of the age groups of patients. Special caution must be exercised with patients on echothiophate iodide eyedrops when succinylcholine or ester-type, hydrolysable local anaesthetics are administered in order to prevent prolonged apnoea and/or toxic reactions.

\section{RÉSUMÉ}

Nous avons étudié l'activité cholinestérasique du plasma chez soixante-et-onze malades qui, durant des périodes allant de deux mois à sept ans, avaient été traités avec de l'iodure d'échothiophate en gouttes dans les yeux. Nous avons recherché les taux d'hydrolyse du chlorure de benzoylcholine et du chlorhydrate de procaïne. Parmi les soixante et onze malades étudiés, 37 pour cent avaient un taux d'hydrolyse inférieur a 50 pour cent de la normale. Les taux d'hydrolyse de la benzoylcholine des malades mâles et femelles, dont l'activité était normale, ont été de $104.5 \pm$ et de $81.4 \pm 23$ et ceux de la procaine pour les hommes et les femmes étaient $1.12 \pm 0.23$ et $1.09 \pm 0.34$ micromole $/ 1 \mathrm{hre} . / 1 \mathrm{ml}$. de plasma. Les taux d'hydrolyse des malades mâles et femelles, dont l'activité était réduite, étaient $44.0 \pm 15.9$ et $28.0 \pm 16.1$ pour la benzoylcholine et, pour la procaïne, ils étaient $0.551 \pm 0.186$ et $0.370 \pm 0.138$ micromoles $/ 1$ hre. $/ 1 \mathrm{ml}$. de plasma. Etant donné que, un malade sur sept avait au delà de 75 pour cent de réduction de son activité enzymatique et quelques uns même avaient une réduction supérieure à 90 pour cent il s'impose d'être prudent dans l'usage, chez de tels malades traités par l'iodide d'échothiophate du chlorure de succinylcholine, de certains agents anesthésiques locaux du type ester, de façon à prévenir l’apnée et, respectivement, les réactions toxiques.

\section{ACKNOWLEDGMENTS}

We are indebted to Joseph F. Novak, M.D., Clinical Assistant Professor, Department of Ophthalmology, University of Pittsburgh School of Medicine, for making patients available for this study and for his suggestions during the investigations. 


\section{REFERENCES}

1. Leopold, I. H.; GoLd, P.; \& GoLd, D. Use of Thiophosphynil Quaternary Compounds (217-MI) in Treatment of Glaucoma. Arch. Ophthal. 58: 363 (1957).

2. Leopold, I. H.; Krishna, N.; \& Lehman, R. Effects of Anticholinesterase Agents on Blood Cholinesterase in Normal and Glaucomatous Subjects. Trans. Am Ophthal. Soc. 57: 63 (1957).

3. Leopold, I. H. Ocular Cholinesterase and Cholinesterase Inhibitors. Am. J. Ophthal. 51: 885 (1961).

4. Humphreys, J. \& Holmes, J. Systemic Effects Produced by Echothiophate Iodide in the Treatment of Glaucoma. Arch. Ophthal. 69: 737 (1963).

5. WAHL, J. W. \& TYNER, G. S. Echothiophate Iodide: The Effect of $0.0625 \%$ Solution on Blood Cholinesterase. Am. J. Ophthal. 60: 419 (1965).

6. Hiscox, P. E. \& McCulloch, C. Cardiac Arrest Occurring in a Patient on Echothiophate Iodide Therapy. Am. J. Ophthal. 60: 425 (1965).

7. TAMMELIN, L.-E. Organophosphorylcholines and Cholinesterases. Ark. kemi. 12: 287 (1958).

8. Foldes, V. M.; Foldes, F. F.; \& Zsigmond, E. K. The In Vivo and In Vitro AntiCholinesterase Effect of Phospholine Iodide in Man. Fed. Proc. 20: 236 (1961).

9. Pantuck, E. J. Echothiophate Iodide Eyedrops and Prolonged Response to Suxamethonium. Brit. J. Anaesth. 38: 406 (1966).

10. Gesztes, Th. Prolonged Apnoea after Suxamethonium Injection Associated with Eyedrops Containing an Anticholinesterase Agent: A Case Report. Brit. J. Anaesth. 38: 408 (1966).

11. Kalow, W. Relationship of Plasma Cholinesterase to Response to Clinical Doses of Succinylcholine. Canad. Anaesth. Soc. J. 3: 22 (1956).

12. Foldes, F. F.; Foldes, V. M.; SMith, J. C.; \& Zsigmond, E. K. The Relation between Plasma Cholinesterase and Prolonged Apnea Caused by Succinylcholine. Anesthesiology. 23: 208 (1963).

13. Foldes, F. F.; Swerwlow, M.; Lipschitz, E.; VanHees, G. R.; \& Shanor, S. P. Comparison of the Respiratory Effects of Suxamethonium and Suxethonium. Anesthesiology. 17: 559 (1956).

14. Aucustinsson, K.-B. The Normal Variation of Human Blood Cholinesterase Activity. Acta physiol, scandinav, 35: 40 (1955).

15. Shanor, S. P.; VanHees, G. R.; BaArT, N.; Erdös, E. G.; \& Foldes, F. F. The Influence of Age and Sex on Human Plasma and Red Cells Cholinesterase. Am. J. Med. Sc. 242: 357 (1961).

16. Shnwern, S. M. Serum Cholinesterase Activity during Pregnancy, Labor and the Puerperium. Anesthesiology. 26: 335 (1965).

17. Zsigmond, E. K.; Pattenson, R. L.; \& Downs, J. R. Plasma Cholinesterase Activity of Neonates and Infants. Paper presented at the Annual Meeting of the A.M.A., Section on Anesthesiology, June 1967, Atlantic City, New Jersey.

18. Kalow, W. Hydrolysis of Local Anesthetics by Human Plasma Cholinesterase. J. Pharmacol. Exper. Therap. 104: 122 (1952).

19. Kalow, W. \& Staron, N. On Distribution and Inheritance of Human Serum Cholinesterase, as Indicated by Dibucaine Number. Canad. J. Biochem. Physiol. 35: 1305 (1957).

20. Foldes, F. F.; Molloy, R.; McNall, P. G.; \& Koukal, L. R. Comparison of the Toxicity of Intravenously Given Local Anesthetic Agents in Man. J.A.M.A. 172: 1493 (1960).

21. Kalow, W. \& Genest, K. A Method for the Detection of Atypical Forms of Serum Cholinesterase: Determination of Dibucaine Numbers. Canad. J. Biochem. Physiol. 35: 339 (1957).

22. Wouff, H. Inhibition of Serum Cholinesterase by Cyclophosphamide. Klin. Wchnschr. 43: 819 (1965). 